\title{
Effect of copper supplementation on indices of copper status and certain CVD risk markers in young healthy women
}

\author{
Susanne Bügel ${ }^{1 *}$, Angela Harper ${ }^{1}$, Edmond Rock ${ }^{2}$, Jacqueline M. O’Connor ${ }^{3}$, Maxine P. Bonham ${ }^{3}$ \\ and J. J. Strain ${ }^{3}$ \\ ${ }^{1}$ Department of Human Nutrition and Centre for Advanced Food Studies, Royal Veterinary and Agricultural University, Rolighedsvej 30, \\ DK-1958 Frederiksberg C, Denmark \\ ${ }^{2}$ INRA, Clermont Ferrand, France \\ ${ }^{3}$ Northern Ireland Centre for Food \& Health (NICHE), University of Ulster, Cromore Road, Coleraine, BT52 1SA, Northern Ireland, UK
}

(Received 8 July 2004 - Revised 3 January 2005 - Accepted 22 February 2005)

\begin{abstract}
Western diets containing suboptimal $\mathrm{Cu}$ concentrations could be widespread. A link between marginal Cu deficiency and CVD has been suggested. The objective of the present study was to investigate the effect of Cu supplementation on both Cu status and CVD risk factors in healthy young women. Sixteen women with a mean age of 24 (SD 2) years participated in a randomised crossover study of three 4-week periods with 3-week washouts between periods. During each intervention period, subjects received 0,3 or $6 \mathrm{mg}$ elemental $\mathrm{Cu} / \mathrm{d}$ as $\mathrm{CuSO}_{4}$ in addition to their habitual diet. Blood samples were taken to assess the effect of supplementation on putative markers of $\mathrm{Cu}$ status. The content of plasma lipids, lipoprotein (a), apo and certain haemostatic factors, as putative indices of CVD, was also analysed. Daily supplementation with $3 \mathrm{mg} \mathrm{Cu}$ significantly increased $(P<0 \cdot 05)$ serum Cu concentration and the activity of erythrocyte superoxide dismutase, although there was no further significant increase after an intake of $6 \mathrm{mg} \mathrm{Cu} / \mathrm{d}$. The concentration of the fibrinolytic factor plasminogen activator inhibitor type 1 was significantly reduced $(P<0.05)$ by about $30 \%$ after supplementation with $6 \mathrm{mg} \mathrm{Cu} / \mathrm{d}$. No other marker of $\mathrm{Cu}$ status or CVD risk factor was affected by $\mathrm{Cu}$ supplementation. The results indicate that supplementation with 3 or $6 \mathrm{mg} \mathrm{Cu} / \mathrm{d}$ may improve $\mathrm{Cu}$ status in these healthy young women. Increased $\mathrm{Cu}$ intake could reduce the risk of CVD and atherosclerosis in man by promoting improved fibrinolytic capacity.
\end{abstract}

Cu status: Cu supplementation: Marginal Cu deficiency: CVD

Clinically significant $\mathrm{Cu}$ deficiency is rare in man, suggesting that the current dietary intake is usually adequate for requirements. $\mathrm{Cu}$ deficiency has been reported mostly in infants recovering from malnutrition, in premature infants fed cows' milk diets or during total parenteral nutrition with inadequately supplemented preparations (Danks, 1988). Deficiency is associated with a low concentration of both serum $\mathrm{Cu}$ and caeruloplasmin $(\mathrm{Cp})$, clinical features including anaemia, leucopenia and osteoporosis. A new RDA for $\mathrm{Cu}$ of $0.9 \mathrm{mg} / \mathrm{d}$ has recently been published (Food and Nutrition Board, 2001) based on an estimated average requirement of $0.7 \mathrm{mg} / \mathrm{d}$, and it has been reported that $0.8 \mathrm{mg} \mathrm{Cu} / \mathrm{d}$ is sufficient to maintain $\mathrm{Cu}$ status in men (Turnlund et al. 1990). The recommendation is, however, based on data from only three studies involving thirty-two men and women, and may therefore be inappropriate. More than $30 \%$ of diets in North America and Europe contain less than $1.0 \mathrm{mg} \mathrm{Cu} / \mathrm{d}$ (Klevay et al. 1993), and in a more recent study conducted in Maryland, USA, dietary $\mathrm{Cu}$ intake was below the current RDA in $60 \%$ of the population (Pang et al. 2001). It has been suggested that marginal $\mathrm{Cu}$ deficiency could be linked to a number of degenerative and inflammatory conditions, including arthritis, cancer, osteoporosis and CVD (Strain, 1994; Klevay, 1998; Milne, 1998).

Many studies have reported adverse effects of $\mathrm{Cu}$ deficiency on risk factors for CVD in experimental animals. Cardiovascular abnormalities associated with such $\mathrm{Cu}$ deficiency have included hypercholesterolaemia (Klevay, 1975; Allen \& Klevay, 1978; Lau \& Klevay, 1981), increased susceptibility of VLDL and LDL to oxidation in vitro (Rayssiguier et al. 1993) and irregular electrocardiograms (Viestenz \& Klevay, 1982; Medeiros et al. 1991a). A severe impairment of fibrinolysis has also been observed in $\mathrm{Cu}$-deficient mice (Lynch \& Klevay, 1993). A number of short-term human studies of experimental $\mathrm{Cu}$ deprivation have shown inconsistent results (reviewed in Milne, 1998). Adverse changes such as abnormal electrocardiograms (Reiser et al. 1985) and increased serum cholesterol (Klevay et al. 1984; Reiser et al. 1987; Nielsen et al. 1990) have again been reported, although usually in the absence of conventional biochemical signs of $\mathrm{Cu}$ deficiency. Some of the abnormalities in CVD risk factors were observed with $\mathrm{Cu}$ intakes of between 0.8 and $1.0 \mathrm{mg} / \mathrm{d}$, which has tended to support the claim for an

Abbreviations: $\mathrm{CCO}$, cytochrome C oxidase; $\mathrm{Cp}$, caeruloplasmin; PAI-1, plasminogen activator inhibitor type 1; SOD, superoxide dismutase; t-PA, tissue plasminogen activator; TGF- $\beta$, transforming growth factor- $\beta$; WBC, leucocyte.

Reprints not available

* Corresponding author: Dr Susanne Bügel, fax +45 352824 83, email shb@kvl.dk 
association between low dietary $\mathrm{Cu}$ and CVD (Klevay, 1998) and may also suggest that the current RDA for $\mathrm{Cu}$ is too low.

Few studies have investigated the effect of dietary $\mathrm{Cu}$ intake on $\mathrm{Cu}$ status in women (Johnson et al. 1988; Milne et al. 1988; Johnson et al. 1992), despite evidence of some differences in $\mathrm{Cu}$ metabolism between men and women (Johnson et al. 1992). The aim of the present study was therefore to examine $\mathrm{Cu}$ status indicators and certain risk markers for CVD (including plasma lipids, lipoproteins and haemostatic factors) in young women during supplementation with $\mathrm{Cu}$. The study was conducted as part of a multicentre European study (FOODCUE), which was undertaken to provide data on the biological effects of increased dietary $\mathrm{Cu}$.

\section{Subjects and methods}

\section{Subjects}

Sixteen apparently healthy women aged 21-28 years were recruited for the study and were asked to maintain a normal lifestyle. The subjects' mean baseline characteristics were as follows: age 24 (SD 2) years, weight 60 (SD 7) $\mathrm{kg}$, height 166 (SD 8) cm, BMI 21 (SD 2) $\mathrm{kg} / \mathrm{m}^{2}$. Exclusion criteria included smoking, the use of dietary supplements or oral contraceptives, pregnancy, breast-feeding and participation in competitive sports. Ethical approval was obtained from the Local Research Ethics Committee for Copenhagen and Frederiksberg (Journal no. 01-065/96), and all subjects signed an informed consent document.

\section{Experimental design}

The study was a double-blind, placebo-controlled randomised crossover trial, consisting of three 4-week periods, with a minimum 3 -week washout between periods. Subjects received 0, 3 or $6 \mathrm{mg}$ elemental $\mathrm{Cu} / \mathrm{d}$ as $\mathrm{CuSO}_{4}$ (Thomson and Joseph Ltd, Norwich, UK) during the 4-week intervention period in the form of a daily capsule in addition to their usual diet. The 4-week supplementation period was considered to be sufficient to enable the detection of any changes in indices of $\mathrm{Cu}$ status and CVD risk markers with the concentrations of $\mathrm{Cu}$ used. Previous studies of $\mathrm{Cu}$ depletion have shown a recovery of superoxide dismutase (SOD) activity after supplementation with at least $3 \mathrm{mg} \mathrm{Cu} / \mathrm{d}$ for at least $30 \mathrm{~d}$, but not with less than $2.6 \mathrm{mg} \mathrm{Cu} / \mathrm{d}$ for up to $42 \mathrm{~d}$ (Milne, 1998). Another study has detected changes in certain CVD indices after 4 weeks with 2 or $3 \mathrm{mg} \mathrm{Cu} / \mathrm{d}$ (Medeiros et al. $1991 b)$. The $6 \mathrm{mg} / \mathrm{d} \mathrm{Cu}$ dose was considered to be a suitably high concentration that was also below the tolerable upper intake level for $\mathrm{Cu}$ of around $10 \mathrm{mg} / \mathrm{d}$ (Food and Nutrition Board, 2001). The $3 \mathrm{mg} / \mathrm{d}$ dose of $\mathrm{Cu}$ was chosen because it was at the top end of the safe and adequate daily allowance of between 1.5 and $3.0 \mathrm{mg} \mathrm{Cu}$ recommended at the time (National Research Council, 1989).

\section{Blood sampling and sample preparation}

After an overnight fast, venous blood samples were taken on the morning of the last day of each 4-week supplementation period. Subjects abstained from alcohol for at least $24 \mathrm{~h}$ and from physical activity for at least $36 \mathrm{~h}$ before sampling. Blood was collected in trace element-free tubes (Vacutainer 606526; Becton Dickinson, Meylan-Cedex, France) for analysis of serum $\mathrm{Cu}$ and C-reactive protein, a marker of systemic inflammation.
Blood samples were allowed to clot at room temperature for $1 \mathrm{~h}$ and were then centrifuged $\left(3000 \mathrm{~g}, 15 \mathrm{~min}, 18^{\circ} \mathrm{C}\right)$. Serum was transferred into plastic vials and stored at $-20^{\circ} \mathrm{C}$.

Blood was drawn into tubes containing citrate (Vacutainer 606608; Becton Dickinson) for determination of erythrocyte $\mathrm{SOD}$ and $\mathrm{Hb}$ activity, and into pre-cooled heparin tubes (Becton Dickin-son) for analysis of leucocyte (WBC) SOD, Cp and cytochrome $\mathrm{C}$ oxidase (CCO). The pre-cooled blood was centrifuged $\left(1700 \mathrm{~g}, 10 \mathrm{~min}, 4^{\circ} \mathrm{C}\right)$, and plasma for $\mathrm{Cp}$ analysis was stored at $-80^{\circ} \mathrm{C}$. The WBC were treated as described in Kehoe et al. (2000), and the WBC pellet subsequently obtained (which did not include platelets) was divided into two, centrifuged $\left(2000 \mathrm{~g}, 10 \mathrm{~min}, 25^{\circ} \mathrm{C}\right.$ ) and then resuspended in either PBS (for SOD analysis) or PBS-EDTA buffer (for CCO analysis) and stored at $-80^{\circ} \mathrm{C}$. Erythrocytes were washed three times in 154 $\mathrm{mM}-\mathrm{NaCl}$, with centrifugation $\left(1700 \mathrm{~g}, 10 \mathrm{~min}, 4^{\circ} \mathrm{C}\right)$, and stored at $-80^{\circ} \mathrm{C}$.

Blood was taken into EDTA tubes (Vacutainer 606457; Becton Dickinson) for analysis of total cholesterol, LDL-cholesterol, HDL-cholesterol and VLDL-cholesterol, total triacylglycerol, LDL-, HDL- and VLDL-triacylglycerol, and apo. Blood for lipoprotein analysis was stored at $-80^{\circ} \mathrm{C}$; blood for lipid analysis was immediately placed on ice and centrifuged $\left(3000 \mathrm{~g}, 15 \mathrm{~min}, 4^{\circ} \mathrm{C}\right)$ before storage at $-20^{\circ} \mathrm{C}$. Blood for analysis of vitamin $\mathrm{E}$ in the LDL fraction was drawn into vacutainer tubes (606430; Becton Dickin-son), EDTA (5\%) was added, and the sample was centrifuged $\left(2000 \mathrm{~g}, 30 \mathrm{~min}, 4^{\circ} \mathrm{C}\right)$. Plasma was removed and sucrose $(0.6 \%)$ added before samples were stored at $-80^{\circ} \mathrm{C}$, after overlaying with $\mathrm{N}$.

Blood was drawn into citrate tubes (Vacutainer 606608; Becton Dickinson) for analysis of fibrinogen and plasma factor VIIc, into stabilyte tubes (Biopool, Umeå, Sweden) for determination of tissue-type plasminogen activator (t-PA) and plasminogen activator inhibitor type 1 (PAI-1), and into diatubes (Becton Dickinson) for transforming growth factor $\beta$ (TGF- $\beta$ ), platelet factor 4 and $\beta$-thromboglobulin analysis. Samples for analysis of TGF- $\beta$ were cooled and centrifuged $\left(700 \mathrm{~g}, 5 \mathrm{~min}, 4^{\circ} \mathrm{C}\right)$ prior to storage at $-80^{\circ} \mathrm{C}$. Samples for PAI-1, t-PA and $\beta$-thromboglobulin analysis were centrifuged $\left(3000 \mathrm{~g}, 15 \mathrm{~min}, 4^{\circ} \mathrm{C}\right)$ and the plasma was transferred into plastic vials and stored at $-80^{\circ} \mathrm{C}$. Samples for platelet factor 4 analysis were centrifuged $(2500 \mathrm{~g}, 30 \mathrm{~min}$, $4^{\circ} \mathrm{C}$ ), and platelet-depleted plasma was carefully liberated and stored in plastic tubes at $-80^{\circ} \mathrm{C}$.

\section{Analytical methods}

Serum copper and $C$-reactive protein. Serum $\mathrm{Cu}$ was determined by atomic absorption spectrometry (Spectra AA-200; Varian, Victoria, Australia), under standard flame operating conditions as recommended by the manufacturer. A standard reference solution for $\mathrm{Cu}$ in serum (Seronorm Trace Element Serum; Nycomed Pharma AS, Oslo, Norway) was run simultaneously. The reference value was $19.8 \mu \mathrm{mol} / \mathrm{l}$ and the mean and standard deviation analysed values ( $n$ 5) were 18.23 (SD 0.59) $\mu \mathrm{mol} / \mathrm{l}$. Serum C-reactive protein levels were measured by an immunoassay (Roche, Basel, Switzerland) using a Cobas Mira automatic analyser (Roche).

Superoxide dismutase, caeruloplasmin and cytochrome $C$ oxidase activity. Determination of erythrocyte SOD activity, serum $\mathrm{Cp}$ oxidase activity and $\mathrm{Hb}$ concentration was performed as described previously (Kehoe et al. 2000). The activity of 
WBC SOD was measured on a Cobas Fara automatic analyser (Roche), by modification of the method of Jones \& Suttle (1981), using a commercial kit (Ransod; Randox Laboratories, Co. Antrim, Northern Ireland). WBC SOD activity was expressed as units/g protein (Bio-Rad protein assay; Bio-Rad, Hemel Hempstead, Herfordshire, UK).

WBC CCO activity was determined as described previously (Kehoe et al. 2000). Results were expressed as units/g protein (Bio-Rad protein assay; Bio-Rad).

Analysis of plasma lipids and vitamin E. Total plasma cholesterol and triacylglycerol concentrations were analysed using an enzymatic procedure (Boehringer Mannheim GmbH, Mannheim, Germany) on the Cobas Mira analyser (Roche). Total HDL-cholesterol was measured enzymatically after precipitation with polyethylene glycol (Quantolip; Immuno AG, Vienna, Austria). The VLDL fraction was separated by ultracentrifugal flotation of fresh plasma $\left(125000 \mathrm{~g}, 16 \mathrm{~h}, 4^{\circ} \mathrm{C}\right)$ at a density of $1.006 \mathrm{~g} / \mathrm{l}$ in a Beckman $50 \mathrm{~T}: \mathrm{L}$ rotor (Beckman Instruments, AL, USA). Accuracy was ensured by use of a control serum of known value (Precinorm L; Boehringer Mannheim). LDL-cholesterol was calculated as the difference between the HDL and VLDL fractions.

The vitamin E content of LDL was measured by HPLC as described previously (Rock et al. 2000).

Analysis of lipoprotein (a) and apo. The concentrations of lipoprotein (a), apo A-1 and apo B were determined by rate nephelometry using a Beckman Array 360 analyser (Global Medical Instrumentation, Inc., Minnesota, USA).

Measurement of haemostatic factors. The plasma concentration of clottable fibrinogen was determined by a modified Clauss assay (1957)*** using a commercial kit (Multifibren U; Dade Behring $\mathrm{GmbH}$, Liederbach, Germany). A commercial ELISA kit was used for analysis of TGF- $\beta$ (Quantikine; R\&D Systems Inc., MN, USA), using an ELISA reader (SLT Rainbow; SLT LabInstruments Diagnostica GmbH, Salzburg, Austria). The total plasma antigen concentration of t-PA and PAI-1 was also determined by an ELISA method using commercial kits (Chromolize (t-PA) and TintElize (PAI-1); Biopool). Accuracy was ensured by use of a fibrinolysis reference plasma (Biopool). The values obtained were 1.10 (SD 0.13) IU/ml ( $n$ 9) and 22.78 (SD 2.54) ng/ $\mathrm{ml}$ ( $n$ 10), compared with certified values of 0.9 (SD 0.04 ) IU/ml and 24.2 (SD 0.4) ng/ml, for t-PA and PAI-1, respectively.

Plasma factor VIIc was determined in a one-stage clotting assay using an ACL300 (Instrumentation Laboratory SpA, Milan, Italy), by incubation of $50 \mu$ l diluted test plasma (1:10 $\mathrm{v} / \mathrm{v}$ in Tris buffer) with added human factor VII-deficient plasma (Biopool) and Tromborel S (Behring Diagnostics, Liederbach, Germany). Factor VIIc was expressed relative to an internal standard: CV \% 3.69 (n 24).
Plasma platelet factor 4 and $\beta$-thromboglobulin were determined using commercial ELISA kits (Asserachrom; Diagnostica Stago, Asnieres-sur-Seine, France). Accuracy was verified by using appropriate reference material (Diagnostica Stago). Values obtained were $81.9(\mathrm{SD} 6.8) \mathrm{IU} / \mathrm{ml}(n 12)$ and 145.7 (SD 18.6) $\mathrm{IU} / \mathrm{ml}$ ( $n$ 14) compared with certified values of 81 (range 68-94) IU/ml and 149 (127-171) IU/ml, for PF-4 and $\beta$-thromboglobulin, respectively.

\section{Statistical analysis}

Data are expressed as means and standard deviations. Data were analysed by the general linear model-repeated measures test using the Statistical Package for the Social Sciences version 8.0 (SPSS Inc., Chicago, IL, USA). Statistical significance was analysed by ANOVA with repeated measures, after confirming that there were no significant carry-over effects. The paired $t$ test was used to make comparisons between individual treatments. A significance level of $P<0.05$ was used for all statistical tests (two-sided).

\section{Results}

The effect of $\mathrm{Cu}$ supplementation on putative indices of $\mathrm{Cu}$ status in young women is shown in Table 1 . There was a significant increase $(P=0.04)$ of about $14 \%$ compared with placebo in the concentration of serum $\mathrm{Cu}$ after daily supplementation with $3 \mathrm{mg} \mathrm{Cu}$ for 4 weeks. Supplementation with $6 \mathrm{mg} \mathrm{Cu} / \mathrm{d}$ led to no further significant increase. Similarly, addition of $3 \mathrm{mg} \mathrm{Cu} / \mathrm{d}$ to the habitual diet significantly increased $(P=0.03)$ erythrocyte SOD activity by about $11 \%$ compared with placebo, whereas there was no further significant increase with $6 \mathrm{mg} \mathrm{Cu} / \mathrm{d}$ supplementation.

The activity of both WBC SOD and serum Cp increased by about $12 \%$ and $16 \%$, respectively, after supplementation with $3 \mathrm{mg} \mathrm{Cu} / \mathrm{d}$ compared with placebo, but these increases were not significant $(P>0.05)$. The activity of WBC CCO was unaffected by $\mathrm{Cu}$ supplementation. $\mathrm{C}$-reactive protein concentrations were measured in twelve samples for each subject. Levels were below $5 \mathrm{mg} / \mathrm{l}$ in all samples, except for one subject who had raised levels of 8 and $7 \mathrm{mg} / \mathrm{l}$ in the first and last sample, respectively. These values were only slightly above the normal C-reactive protein level of $<6 \mathrm{mg} / \mathrm{l}$ and did not appear to be associated with any adverse effect on the results for that subject.

The effect of $\mathrm{Cu}$ supplementation on risk markers for CVD is shown in Tables 2 and 3. There was no significant effect of any $\mathrm{Cu}$ supplementation treatment on the total plasma concentrations of cholesterol or triacylglycerol, including the LDL, HDL and VLDL fractions of both these lipid components (Table 2).

Table 1. Putative indices of $\mathrm{Cu}$ status in healthy female subjects given 0 (placebo), 3 and $6 \mathrm{mg} \mathrm{Cu} / \mathrm{d}$, each for 4 weeks

\begin{tabular}{|c|c|c|c|c|c|c|}
\hline & \multicolumn{2}{|c|}{ Placebo } & \multicolumn{2}{|c|}{$3 \mathrm{mg} \mathrm{Cu}$} & \multicolumn{2}{|c|}{$6 \mathrm{mg} \mathrm{Cu}$} \\
\hline & Mean & SD & Mean & SD & Mean & SD \\
\hline Serum Cu $(\mu \mathrm{mol} / \mathrm{l})(n 16)$ & $14 \cdot 7$ & 3.9 & $16 \cdot 7^{\star}$ & $6 \cdot 2$ & $17 \cdot 6^{*}$ & 6.9 \\
\hline Erythrocyte superoxide dismutase $(\mathrm{U} / \mathrm{g} \mathrm{Hb})(n 15)$ & 742 & 144 & $825^{\star}$ & 236 & $816^{\star}$ & 176 \\
\hline Leucocyte superoxide dismutase (U/g protein) ( $n$ 14) & 1.62 & 0.4 & 1.81 & 0.9 & 1.91 & $1 \cdot 3$ \\
\hline Serum caeruloplasmin activity $(\mathrm{U} / \mathrm{l})(n 15)$ & 586 & 195 & 677 & 298 & 623 & 215 \\
\hline Cytochrome $\mathrm{C}$ oxidase activity (U/g protein) ( $n$ 14) & 3.32 & 1.5 & $3 \cdot 15$ & 1.9 & 3.69 & 1.4 \\
\hline
\end{tabular}

Mean value was significantly different from placebo group, ${ }^{*} P<0.05$. 
Table 2. Plasma lipid, lipoprotein (a) and apo concentrations in female subjects ( $n$ 16) given 0 (placebo), 3 and $6 \mathrm{mg} \mathrm{Cu} / \mathrm{d}$, each for 4 weeks

\begin{tabular}{|c|c|c|c|c|c|c|}
\hline & \multicolumn{2}{|c|}{ Placebo } & \multicolumn{2}{|c|}{$3 \mathrm{mg} \mathrm{Cu}$} & \multicolumn{2}{|c|}{$6 \mathrm{mg} \mathrm{Cu}$} \\
\hline & Mean & SD & Mean & SD & Mean & SD \\
\hline Total cholesterol (mmol/l) & 4.5 & 0.9 & 4.5 & 0.9 & 4.4 & 0.7 \\
\hline VLDL-cholesterol & 0.24 & 0.18 & 0.23 & 0.14 & 0.31 & 0.2 \\
\hline LDL-cholesterol & $2 \cdot 82$ & 0.8 & $2 \cdot 80$ & 0.8 & $2 \cdot 77$ & 0.6 \\
\hline HDL-cholesterol & 1.43 & 0.3 & 1.47 & 0.3 & 1.35 & 0.3 \\
\hline Total triacylglycerol (mmol/l) & 0.96 & 0.47 & 0.95 & 0.38 & 1.06 & 0.51 \\
\hline VLDL-triacylglycerol & 0.58 & 0.40 & 0.54 & 0.33 & 0.67 & 0.45 \\
\hline LDL- + HDL-triacylglycerol & 0.39 & 0.11 & 0.41 & 0.11 & 0.39 & 0.11 \\
\hline Lipoprotein(a) (g/l) & 0.20 & 0.37 & 0.16 & 0.26 & 0.19 & 0.31 \\
\hline Apo A-1 (g/l) & 1.7 & 0.2 & $1 \cdot 8$ & 0.4 & 1.7 & 0.2 \\
\hline Apo B $(g / l)$ & 1.04 & 0.3 & 0.99 & 0.29 & 0.98 & 0.26 \\
\hline
\end{tabular}

The content of vitamin $\mathrm{E}$ in the LDL fraction was similarly unaltered by $\mathrm{Cu}$ intake (with values of 2.4 (SD 1.1$) \mu \mathrm{g} / \mathrm{ml}, 2.2$ (SD 1.2$) \mu \mathrm{g} / \mathrm{ml}$ and 2.2 (SD 0.8$) \mu \mathrm{g} / \mathrm{ml}$ for supplementation with 0,3 and $6 \mathrm{mg} \mathrm{Cu} / \mathrm{d}$, respectively).

There was no significant effect of any $\mathrm{Cu}$ supplementation regime on the plasma concentrations of lipoprotein (a), apo A-1 and apo B (Table 2).

The effect of $\mathrm{Cu}$ supplementation on a number of haemostatic factors associated with thrombosis was also investigated in the present study (Table 3). The concentrations of coagulation factors fibrinogen and factor VIIc were unaffected by increased $\mathrm{Cu}$ intake. In contrast, there was a significant decrease $(P=0.04)$ in the concentration of the fibrinolytic factor PAI- 1 of about $30 \%$ after supplementation with $6 \mathrm{mg} \mathrm{Cu} / \mathrm{d}$ compared with placebo. There was a similar decrease after an intake of $3 \mathrm{mg} \mathrm{Cu} / \mathrm{d}$ (about $15 \%$ ), although this was not significant $(P>0.05)$. The decrease in PAI-1 was accompanied by a simultaneous non-significant increase in the measured activity of t-PA.

There was no effect of $\mathrm{Cu}$ supplementation on the concentration of the inflammatory cytokine TGF- $\beta$ in the present study (Table 3). The activity of platelet factor 4 and $\beta$-thromboglobulin was also unaffected by $\mathrm{Cu}$ intake. The standard deviations for platelet factor 4 were particularly high and were probably caused by artefacts introduced during phlebotomy.

\section{Discussion}

The improved $\mathrm{Cu}$ status observed after $\mathrm{Cu}$ supplementation in the present study, illustrated by significantly increased serum $\mathrm{Cu}$ and erythrocyte SOD activity and a tendency towards increased $\mathrm{Cp}$ and WBC SOD activity, indicates that these women may have been marginally $\mathrm{Cu}$ deficient. Studies of short-term $\mathrm{Cu}$ deprivation have shown variable results with regard to putative markers of $\mathrm{Cu}$ status. Plasma $\mathrm{Cu}$ and $\mathrm{Cp}$ are relatively insensitive indicators (Milne \& Nielsen, 1996). Several studies have been unable to demonstrate significant changes in plasma $\mathrm{Cu}$ concentrations with low $\mathrm{Cu}$ intakes for varying periods (Reiser et al. 1985; Milne et al. 1988; Milne \& Nielsen, 1996). Other studies have seen no increase in serum $\mathrm{Cu}$ after $\mathrm{Cu}$ supplementation (Salmenpera et al. 1989; Medeiros et al. 1991b). Previous studies have also shown variable results for Cp (Milne et al. 1988; Milne, 1998; Kehoe et al. 2000).

The Cu-dependent enzymes such as erythrocyte SOD and CCO are generally considered to be more reliable indicators of $\mathrm{Cu}$ status. Some studies have shown changes in erythrocyte SOD or $\mathrm{CCO}$ (erythrocyte, WBC or platelet) during $\mathrm{Cu}$ deprivation or supplementation, in the absence of changes in circulating $\mathrm{Cu}$ or Cp (Reiser et al. 1985; Milne et al. 1988; Milne \& Nielsen, 1996). The increase in erythrocyte SOD observed in the study after supplementation with 3 or $6 \mathrm{mg} \mathrm{Cu} / \mathrm{d}$ might therefore be a more reliable indicator that the subjects had a suboptimal $\mathrm{Cu}$ status. Studies of $\mathrm{Cu}$ deprivation resulting in a reduced activity of erythrocyte SOD have demonstrated that activity can be restored by the subsequent intake of at least $3 \mathrm{mg} \mathrm{Cu} / \mathrm{d}$ (Klevay et al. 1984; Reiser et al. 1985; Milne et al. 1990), but not by amounts of $<2.7 \mathrm{mg} \mathrm{Cu} / \mathrm{d}$ (Milne et al. 1988; Milne \& Nielsen, 1996). This is consistent with the present results. However, other short-term studies of $\mathrm{Cu}$ supplementation for up to 8 weeks in both men and women with the same intakes (3 or $6 \mathrm{mg} \mathrm{Cu} / \mathrm{d}$ ) have shown no effect on erythrocyte SOD activity

Table 3. Haemostatic factors measured in healthy female subjects ( $n$ 16) given 0 (placebo), 3 and $6 \mathrm{mg}$ $\mathrm{Cu} / \mathrm{d}$, each for 4 weeks

\begin{tabular}{|c|c|c|c|c|c|c|}
\hline & \multicolumn{2}{|c|}{ Placebo } & \multicolumn{2}{|c|}{$3 \mathrm{mg} \mathrm{Cu}$} & \multicolumn{2}{|c|}{$6 \mathrm{mg} \mathrm{Cu}$} \\
\hline & Mean & SD & Mean & SD & Mean & SD \\
\hline Fibrinogen $(g / l)$ & $3 \cdot 0$ & 1.4 & $2 \cdot 7$ & $1 \cdot 0$ & $2 \cdot 9$ & $1 \cdot 1$ \\
\hline Factor VIIc (IU/ml) & 0.97 & 0.24 & 0.96 & 0.20 & 0.93 & $0 \cdot 18$ \\
\hline Tissue plasminogen activator (IU/ml) & 0.65 & 0.4 & 0.68 & 0.4 & 0.73 & 0.3 \\
\hline Plasminogen activator inhibitor-1 (ng/ml) & 7.9 & 4.5 & $6 \cdot 7$ & $2 \cdot 8$ & $5 \cdot 5^{*}$ & $3 \cdot 2$ \\
\hline Transforming growth factor- $\beta$ (ng) & $65 \cdot 5$ & 24.5 & $65 \cdot 7$ & $26 \cdot 8$ & 61.4 & $25 \cdot 2$ \\
\hline Platelet factor $4(\mathrm{IU} / \mathrm{ml})$ & $7 \cdot 0$ & $12 \cdot 4$ & 7.9 & $8 \cdot 6$ & $6 \cdot 0$ & 4.5 \\
\hline$\beta$-Thromboglobulin (IU/ml) & 29 & 15 & 21 & $7 \cdot 4$ & 31 & 17 \\
\hline
\end{tabular}

Mean value was significantly different from placebo group, ${ }^{*} P<0.05$ 
(Baker et al. 1999; Kehoe et al. 2000; Rock et al. 2000; Harvey et al. 2003), whereas a recent study of long-term $\mathrm{Cu}$ supplementation showed increases in some indices of $\mathrm{Cu}$ status, including $\mathrm{SOD}$, after high $(7 \mathrm{mg} / \mathrm{d}) \mathrm{Cu}$ intake for 5 months (Turnlund et al. 2004). We consider it most likely that the habitual diet of these young Danish women was inadequate compared with other groups with regard to $\mathrm{Cu}$. This is supported by our overall findings of both increased erythrocyte SOD and serum $\mathrm{Cu}$ and nonsignificant increases in Cp and WBC SOD after supplementation. In addition, SOD activity in the placebo periods of the other short-term studies (Baker et al. 1999; Kehoe et al. 2000; Rock et al. 2000) was always higher than the placebo SOD activity in the present study, whereas SOD activity after 5 months' supplementation (Turnlund et al. 2004) increased well above the levels obtained in the current study. No published data are available regarding dietary $\mathrm{Cu}$ intake in Danish women. A study of young Danish men reported $\mathrm{Cu}$ intake to be 1.2 (SD 0.6) $\mathrm{mg} \mathrm{Cu}$ / $10 \mathrm{MJ}$ (Bro et al. 1990), and intakes for women appear to be less than for men (Johnson et al. 1992).

Increases in serum cholesterol concentrations are a consistent consequence of $\mathrm{Cu}$ deficiency in animal studies (Klevay, 1975; Allen \& Klevay, 1978; Lau \& Klevay, 1981). Changes in cholesterol concentration during short-term studies of $\mathrm{Cu}$ deprivation in human subjects have been much less consistent. Only a few studies have reported increased total cholesterol with $\mathrm{Cu}$ depletion (Klevay et al. 1984; Reiser et al. 1987; Nielsen et al. 1990), whereas cholesterol concentrations in other studies were unchanged (Milne et al. 1988; Turnlund et al. 1990; Milne \& Nielsen, 1996). In the present study, we found no significant changes in total cholesterol or triacylglycerol, including lipoprotein fractions, or in lipoprotein (a), apo A-1 and apo B. This was in agreement with other studies that found no effect on certain CVD risk factors in men after supplementation with between 0.7 and $6 \mathrm{mg} \mathrm{Cu} / \mathrm{d}$ (Jones et al. 1997; Harvey et al. 2003). It is possible that effects are seen only during more severe $\mathrm{Cu}$ deprivation, over a longer supplementation period or in subjects already at risk.

Impairment of the haemostatic system is also associated with thrombosis and atherosclerosis, and there is some evidence that $\mathrm{Cu}$ deprivation may promote these events (Lynch \& Klevay, 1993; Klevay, 1998). Cu is known to have a role in blood clotting through factors $\mathrm{V}$ and VIII, both of which increase during $\mathrm{Cu}$ depletion in human subjects (Milne \& Nielsen, 1996). We found no effect of $\mathrm{Cu}$ supplementation on any haemostatic factor except PAI-1, which was significantly decreased after supplementation with $6 \mathrm{mg} \mathrm{Cu} / \mathrm{d}$. PAI- 1 helps to regulate thrombogenesis via an inhibition of fibrinolysis, and high PAI-1 activity has been shown to be a risk factor for atherosclerosis and thrombosis (Aznar \& Estelle, 1994). An effect of $\mathrm{Cu}$ could be mediated through activated protein $\mathrm{C}$, as activated protein $\mathrm{C}$ decreases the level of PAI-1 and the $\mathrm{Cu}-$ binding protein $\mathrm{Cp}$ appears to play an important role in the regulation of this anticoagulant protein. Cp inhibits the activated protein C-catalysed inactivation of coagulation factors Va and VIII (Walker \& Fay, 1990). It is thus possible that if activated protein C activity is reduced during $\mathrm{Cu}$ deficiency, via binding of $\mathrm{Cp}$, a variety of atherogenic factors could be increased.

In conclusion, we found that the young female volunteers who participated in this study appeared to be marginally $\mathrm{Cu}$ deficient when consuming their habitual diet. Both SOD activity and serum $\mathrm{Cu}$ concentration increased after supplementation with 3 and $6 \mathrm{mg} \mathrm{Cu} / \mathrm{d}$ for $28 \mathrm{~d}$. It would be useful to determine the $\mathrm{Cu}$ content of the habitual diet for these women, since it could be representative of an inadequate intake in other (European) populations. Such information is especially relevant in view of the recent establishment of a RDA for $\mathrm{Cu}$ (Food and Nutrition Board, 2001). The only risk marker for CVD that was affected by $\mathrm{Cu}$ supplementation was PAI-1. PAI-1 concentration decreased after $\mathrm{Cu}$ supplementation, but all risk factors measured were within normal ranges for each group. Future studies should perhaps focus on high-risk groups. The effect of $\mathrm{Cu}$ supplementation on the activity of PAI-1 may warrant further investigation.

\section{Acknowledgements}

The authors wish to acknowledge the late Brittmarie Sandström, who was a very valuable partner in this project. We also thank the volunteers who participated in the study and the laboratory technicians Hanne Lysdal Pedersen, Ella Jessen, Majbritt Schwaner and Kirsten Pedersen, who performed the analyses. All authors contributed to the content of this article, intellectually or practically, and made comments on the final draft. None of the authors has any conflicts of interest to declare. The study was carried out with financial support from the Commission of the European Communities, Agriculture and Fisheries (FAIR) specific RTD programme, CT 95-0813. It does not necessarily reflect its views and in no way anticipates the Commission's future policy in this area.

\section{References}

Allen KGD \& Klevay LM (1978) Cholesterolemia and cardiovascular abnormalities in rats caused by $\mathrm{Cu}$ deficiency. Atherosclerosis 29, $81-93$.

Aznar J \& Estelle A (1994) Role of plasminogen activator inhibitor type 1 in the pathogenesis of coronary heart diseases. Haemostasis 24, $243-251$.

Baker A, Turley E, Bonham MO, O'Connor JM, Strain JJ, Flynn A \& Cashman KD (1999) No effect of copper supplementation on biochemical markers of bone metabolism in healthy adults. Br J Nutr 82, 283-290.

Bro S, Sandström B \& Heydorn K (1990) Intake of essential and toxic trace elements in a random sample of Danish men as determined by the duplicate portion sampling technique. $J$ Trace Elem Electrolytes Health Dis 4, 147-155.

Clauss A (1957) Rapid physiological coagulation method for the determination of fibrinogen [German]. Acta Haematol 17, 237-246.

Danks DM (1988) Copper deficiency in humans. Аnпи Rev Nutr 8, $235-257$.

Food and Nutrition Board (2001) Copper. In Dietary Reference Intakes for Vitamin A, Vitamin K, Arsenic, Boron, Chromium, Copper, Iodine, Iron, Manganese, Molybdenum, Nickel, Silicon, Vanadium, and Zinc, pp. 224-257 Washington, DC: National Academy Press.

Harvey LJ, Majsak-Newman G, Dainty JR, Lewis DJ, Langford NJ, Crews HM \& Fairweather-Tait SJ (2003) Adaptive responses in men fed low- and high-copper diets. Br J Nutr 90, 161-168.

Johnson PE, Milne DB \& Lykken GI (1992) Effects of age and sex on copper absorption, biological half- life, and status in humans. Am J Clin Nutr 56, 917-925.

Johnson PE, Stuart MA, Hunt JR, Mullen L \& Starks TL (1988) Copper absorption by women fed intrinsically and extrinsically labeled goose meat, goose liver, peanut butter and sunflower butter. J Nutr 118, $1522-1528$.

Jones AA, DiSilvestro RA, Coleman M \& Wagner TL (1997) Copper supplementation of adult men: effects on blood copper enzyme activities 
and indicators of cardiovascular disease risk. Metab Clin Exp 46, $1380-1383$.

Jones DG \& Suttle NF (1981) Some effects of Cu deficiency on leucocyte function in cattle and sheep. Res Vet Sci 31, 151-156.

Kehoe CA, Turley E, Bonham MP, et al. (2000) Response of putative indices of copper status to copper supplementation in human subjects. Br J Nutr 84, 151-156.

Klevay LM (1975) Coronary heart disease: the zinc/Cu hypothesis. Am J Clin Nutr 28, 764-774.

Klevay LM (1998) Lack of a recommended dietary allowance for copper may be hazardous to your health. J Am Coll Nutr 17, 322-326.

Klevay LM, Buchet JP, Bunker VW, et al. (1993) Copper in the Western diet. In Trace Elements in Man and Animals, pp. 207-210 [M Anke, D Meissner and CF Mills, editors]. Gersdorf, Germany: Verlag Media Touristik.

Klevay LM, Inman L, Johnson LK, Lawler M, Mahalko JR, Milne DB, Lukaski HC, Bolonchuk W \& Sandstead HH (1984) Increased cholesterol in plasma in a young man during experimental copper depletion. Metabolism 33, 1112-1118.

Lau BW \& Klevay LM (1981) Plasma lecithin:cholesterol acyltransferase in copper deficient rats. J Nutr 111, 1698-1703.

Lynch SM \& Klevay LM (1993) Effect of a dietary copper deficiency on plasma fibrinolytic activity in male and female mice. Nutr Res 13, 913-922.

Medeiros DM, Liao Z \& Hamlin RL (1991a) Copper deficiency in a genetically hypersensitive cardiomyopathic rat: 3lectrocardiogram, functional and ultrastructural aspects. J Nutr 121, 1026-1034.

Medeiros DM, Milton A, Brunette E \& Stacy L (1991b) Copper supplementation effects on indicators of copper status and serum-cholesterol in adult males. Biol Trace Elem Res. 30, 19-35.

Milne DB (1998) Copper intake and assessment of copper status. Am J Clin Nutr 67, Suppl, 1041S-1045S.

Milne DB, Johnson PE, Klevay LM \& Sandstead HH (1990) Effect of copper intake on balance, absorption, and status indices of copper in men. Nutr Res 10, 975-986.

Milne DB, Klevay LM \& Hunt JR (1988) Effects of ascorbic acid supplements and a diet marginal in copper on indices of copper nutriture in women. Nutr Res 8, 865-873.

Milne DB \& Nielsen FH (1996) Effects of a diet low in copper on copperstatus indicators in postmenopausal women. Am J Clin Nutr 63, $358-364$.
National Research Council (1989) Recommended Dietary Allowances, 10th ed. Washington, DC: National Academy Press.

Nielsen FH, Milne DB, Mullen LM \& Gallagher SK (1990) Dietary sulfur amino acids and genetic make-up or interindividual variation affect the response of men to $\mathrm{Cu}$ depletion. J Trace Elem Exp Med 3, 281-296

Pang Y, MacIntosh DL \& Ryan PB (2001) A longitudinal investigation of aggregate oral intake of copper. J Nutr 131, 2171-2176.

Rayssiguier Y, Gueux E, Bussiere L \& Mazur A (1993) Copper deficiency increases the susceptibility of lipoproteins and tissues to peroxidation in rats. J Nutr 123, 1343-1348.

Reiser S, Powell A, Yang C-Y \& Canary JJ (1987) Effect of copper intake on blood cholesterol and its lipoprotein distribution in men. Nutr Rep Int 36, 641-649.

Reiser S, Smith JC Jr, Mertz W, Holbrook JT, Schofield DJ, Powell AS, Canfield WK \& Canary JJ (1985) Indices of copper status in humans consuming a typical American diet containing either fructose or starch. Am J Clin Nutr 42, 242-251.

Rock E, Mazur A, O'Connor JM, Bonham MP, Rayssiguier Y \& Strain JJ (2000) The effect of copper supplementation on red blood cell oxidizability and plasma antioxidants in middle-aged healthy volunteers. Free Radic Biol Med 28, 324-329.

Salmenpera L, Siimes MA, Nanto V \& Perheentupa J (1989) Copper supplementation: failure to increase plasma copper and ceruloplasmin concentrations in healthy infants. Am J Clin Nutr 50, 843-847.

Strain JJ (1994) Newer aspects of micronutrients in chronic disease: copper. Proc Nutr Soc 53, 583-598.

Turnlund JR, Jacob RA, Keen CL, Strain JJ, Kelley DS, Domek JM, Keyes WR, Ensunsa JL, Lykkesfeldt J \& Coulter J (2004) Long-term high copper intake: effects on indexes of copper status, antioxidant status, and immune function in young men. Am J Clin Nutr 79, $1037-1044$.

Turnlund JR, Keen CL \& Smith RG (1990) Copper status and urinary and salivary copper in young men at three levels of dietary copper. Am J Clin Nutr 51, 658-664.

Viestenz KE \& Klevay LM (1982) A randomized trial of copper therapy in rats with electrocardiographic abnormalities due to copper deficiency. Am J Clin Nutr 35, 258-266.

Walker FJ \& Fay PJ (1990) Characterization of an interaction between protein C and ceruloplasmin. J Biol Chem 265, 1834-1836. 